\title{
Proinflammatory Cytokines in Plasma of Patients with Typhoid Fever and Resistance to Therapy
}

\author{
Eman A. Eissa ${ }^{(1)}$, T.I. EL-Sayed ${ }^{(2)}$, A.A. Attia ${ }^{(2)}$, M.E. Rashed ${ }^{(3)}$ and Heba M. \\ Refaat $^{(2) \#}$ \\ ${ }^{(1)}$ Clinical Pathology Department, Faculty of Medicine, Benha University, Benha, \\ Egypt; (2)Botany Department, Faculty of Science, Benha University, Benha, Egypt; \\ ${ }^{(3)}$ National Organization for Research and Biological Control, Cairo, Egypt.
}

\begin{abstract}
$\mathbf{T}$
YPHOID fever a food-borne disease caused by Salmonella species, is a worldwide prevalent disease. In endemic areas, children are at highest risk owing to weaning from passively acquired maternal antibody and lack of acquired immunity. Several studies have been done to clarify the pathogenesis and underlying immune aspects of typhoid fever.
\end{abstract}

The Objective is to study the changes of some proinflammatory cytokines in plasma of children and adults with typhoid fever and resistance to therapy.

This study included 128 cases from which 34 consecutive children and adult admitted to Benha Fever Hospital with proven diagnosis of typhoid fever patients with typhoid fever resistant to combined therapy with Ciprofloxacin and Cefotax in addition to Zithrokan and Zantac have higher plasma levels of IL-6 and TNF-alpha. Toxic look, constipation and splenomegaly may be considered as indicators of drug resistance.

Study of changes in the levels of some cytokines may offer a new dimension in the assessment of the clinical efficacy of antimicrobial therapy.

Keywords: Salmonella, Typhoid fever, Cytokines.

\section{Introduction}

Salmonella is a genus of rod-shaped (bacillus) gram-negative bacteria of the Enterobacteriaceae family. Salmonella bongori and Salmonella enterica (serovar typhi (S. typhi)) are the two species of Salmonella. The type species Salmonella enterica divided for 6 subspecies. ( $\mathrm{Su} \& \mathrm{Chiu}$, 2007), which contain above 2500 serotypes.

We can find Salmonella enterica subspecies throughout the world in the environment and in animals with warm blood. Also Salmonella bongori is limited to animals with cold blood, especially reptiles (Tortora, 2008). Typhoid fever, paratyphoid fever and food poisoning (Salmonellosis) diseases caused by Strains of Salmonella (Fabrega \& Vila, 2013).

Typhoid fever, a systemic life minatory illness of humans are caued by the bacterial pathogen Salmonella enterica serovar typhi $(S$. typhi) (Dougan \& Paker, 2014 and Wain et al.,
2015). An enteric fever type of illness practically indistinguishable from typhoid also caused by developmentally featured Salmonella serovar, $S$. paratyphi serotype A. (Fangtham \& Wilde, 2005 and Baker et al., 2014). This Salmonella serovars is thus referring to as "Typhoidal Salmonella". We wrote registers in western literature that a typhoid fever was one of the oldest human illness.

The facultative intracellular gram-negative bacillus Salmonella typhi also occasionally Salmonella paratyphi causes typhoid fever. The clinical picture of typhoid fever is different from gram-negative sepsis although Salmonella contain lipopolysaccharide (LPS: bacterial endotoxin) and the function of endotoxin in the pathophysiology of typhoid fever is debatable (Greisman et al., 1969).

The riskiness and the effect of Salmonella infection were determined by various bacterial and host factors. Cytokines were key organizers of the host response to intracellular pathogens (Liles \& Van Voorhis, 1995). Salmonella have distinct

\#Corresponding author email: jonna_2010@yahoo.com DOI: $10.21608 /$ ejm.2018.3992.1061

C2018 National Information and Documentation Center (NIDOC) 
bacterial products which are powerful inducers of cytokines expressions by immune cells (Henderson et al., 1996; Wilson et al., 1998 and Ciacci et al., 1998).

In all regions of the world, Typhoid fever is encountered, these days mostly located in countries wherever hygienic situation are poor. In the developing world, typhoid fever is considered to be one of the main and reported illness. In some regions, typhoid fever was rated that, it is in charge of 2 to $5 \%$ of all fatalities. In many parts of the developing world, clinic case deaths are still high (1 to 35\%) (Levine et al., 1990). The incidence in the US, was 400 cases/year, especially between travelers (2005). Incidence of typhoid fever was evaluated in Eypgt to be 13/1000 000 persons (Crump et al., 2003).

The etiologic organism of typhoid fever is Salmonella typhi which is similar to other Salmonella in that, it is a gram-negative flagellated, non-capsulated, non-sporulating, facultative anaerobic bacillus. It has flagellar $(\mathrm{H})$ antigen (protein), a somatic (O) antigen (oligosaccharide), and an envelope $(\mathrm{K})$ antigen (polysaccharide). Also, has endotoxin (lipopolysaccharide macromolecular complex) which form the external part of the cell wall (Zaidi et al., 2003). Typhoid fever has a main feature which are Cellular immune response which erquires activation of macrophages. Phagocytosis is a main host defense mechanism. Cytokines which are substances emitted from macrophages has a tremendous effect in the pathogenesis of the illness (Mastroeni \& Menager, 2003). Thus this study aims to research the changes in the levels of TNF-alpha and IL-6 is the aim of this study, also the effect of these changes on the clinical course of children and adults who is suffering from typhoid fever.

\section{Materials and Methods}

This study included 128 cases from which 34 consecutive children and adult(19 males and 15 females), of ages ranging from 1.5 to 40 years $(\mathrm{X} \pm \mathrm{SD}: 18.75+10.07)$. They were 18 children (11 males and 7 females) of ages ranging from 1.5-18 years and 16 adult ( 8 males and 8 females) of ages ranging from 19-40 years, who are admitted to Benha Fever Hospital, through the year 2014-2015. The isolate organism proven to Salmonella by stool culture on selenite broth (Keuter et al., 1994).
Ethical approval was obtained from the local research ethics committee and parents of all subjects gave an informed written consent prior to the study.

All patients were given Cefotax (in a dose of $1 \mathrm{gm} / 1 \mathrm{~h}$ ) divided every $6 \mathrm{~h}$ or $12 \mathrm{~h}$ and oral ciprofloxacin tablet $250-750 \mathrm{mg} / 12 \mathrm{~h}$, zithrokan (in a dose of 8 to $10 \mathrm{mg} / \mathrm{kg}$ (maximum: $500 \mathrm{mg} /$ dose) orally once a day) and zantac (in a oral dosage is $150 \mathrm{mg}$ twice daily). According to the response to therapy, at the $7^{\text {th }}$ day (Miller et al., 1995), patients were divided into two groups:

Group I (Responsive): 14 cases (7 males and 7 females), of mean age $20.34 \pm 12.34$ years who displayed clinical improvement with treatment.

Group II (Resistant): 20 cases (12 males and 8 females), of mean age $17.6 \pm 8.29$ years, who did not display improvement after 7 days of therapy. 20 healthy children ( 8 males and 12 females) of mean age 19.2 \pm 7.19 years were studied as control group.

All children were subjected to the following:

1. Clinical history taking including time of outset and character of fever, chills, headache, loss of appetite, constipation or diarrhea and abdominal pain.

2. Physical examination including daily body temperature measurement, heart rate, skin rash and splenomegaly.

3. Routine laboratory examination, including complete blood count (CBC), C-reactive protein (CRP) and erythrocyte sedimentation rate (ESR) (Choo et al., 2001).

The diagnosis of typhoid fever was proven by Widal test using Febrile Serodiagnostic stained bacterial suspensions. The CROMATEST stained antigens are standardized suspensions of killed bacteria intended for the revelation and semiquantitation by agglutination in either slide or tube tests of human serum agglutinins, a group of antibodies developed through some febrile infections such as brucellosis, salmonellosis and certain rickettsiosis (Felix, 1944 and Joint, 1958), Also, isolation of Salmonella typhi after stool culture, according to the procedure qualified (Old, 1996).

4. Measurement of plasma IL-6 and TNF-alpha on approval and on day 7 after treatment. IL-6 measurement was done using a commercially 
available ELISA kit protocol (Assay Max Human Interleukin-6(IL-6) ELISA Kit), Catalog No. Ei1006-1, Lot No. 09411315). TNF-alpha measurement was done using Assay Max Human Tumor Necrosis Factor-alpha (TNF-alpha) ELISA Kit), catalog No. ET2010, Lot No. 05651411). (Engelmann et al., 1990).

\section{$\underline{\text { Results }}$}

Analysis of laboratory and clinical feature showed that most patients suffered from some symptoms as toxic look, constipation, high fever, splenomegaly, headache and diarrhea. $\mathrm{CBC}$ analysis (RBCS, MCV, MCH, MCHC, Hb, HCT and Platelets) was recorded and from which $\mathrm{Hb}$, HCT and platelets increased significantly more prevalent in patients of typhoid fever than control group (Table 1). Also, TNF-alpha and IL-6 plasma levels are highly significant in cases with typhoid fever than in controls both before and after 7 days treatment (Table 1).

Results in Table 2 show that plasma levels of TNF-alpha and IL-6 is higher significantly in responsive cases (group I) than in controls also in resistant cases (group II) than in response cases, both before and after 7 days of treatment.

Results in Table 3 showed that comparison between group I (response) and group II (resistance) which elevated ESR and CRP is significant more common in resistant cases (group II) to treatment of typhoid fever than in response cases (group I).

Also, plasma levels of TNF-alpha and IL-6 are highly significant in resistant cases (group II) than in responsive (group I).

Results in Table 4 showed that TNF-alpha and IL-6 correlated significantly with S.typhi O and H widal test after 7 days of treatment and with ESR values, with non-significant correlation before treatment.

Results in Table 5 showed that widal test titres follow up before and after 7 days of treatment among responsive cases (group I) representing S.typhi O agglutination titre was significant but at $\mathrm{H}$ agglutination titre non-significant. Also, TNF-alpha and IL-6 plasma levels were highly significant before treatment than after 7 days of treatment in responsive (group I).

Results in Table 6 showed that widal test titres follow up before and after 7 days of treatment among resistance cases (group II) representing $S$. typhi $\mathrm{O}$ and $\mathrm{H}$ agglutination titre were nonsignificant.

TABLE 1 . Laboratory characteristics in responsive and resistant patients (Comparison between cases and control groups).

\begin{tabular}{lcccc}
\hline Variable & $\begin{array}{c}\text { Case group (34) } \\
\text { Mean } \pm \text { SD }\end{array}$ & $\begin{array}{c}\text { Control group } \\
\mathbf{( 2 0 )} \\
\text { Mean } \pm \text { SD }\end{array}$ & t test & P value \\
\hline Sex No. (\%) Male Female & $19(55.9 \%)$ & $8(40.0 \%)$ & $\mathrm{X}^{2}=1.27$ & $\mathrm{P}=0.26$ \\
Age & $15(44.1 \%)$ & $12(60.0 \%)$ & 0.18 & 0.86 \\
RBCs & $18.75 \pm 10.07$ & $19.2 \pm 7.19$ & 1.49 & 0.14 \\
Hb & $3.77 \pm 1.06$ & $4.17 \pm 0.66$ & 3.77 & $0.001 * *$ \\
MCV & $11.12 \pm 2.31$ & $13.25 \pm 1.33$ & 0.95 & 0.35 \\
MCH & $79.48 \pm 7.47$ & $81.29 \pm 5.3$ & 1.48 & 0.15 \\
MCHC & $27.46 \pm 4.14$ & $29.1 \pm 3.56$ & 1.33 & 0.19 \\
HCT & $32.02 \pm 2.93$ & $32.99 \pm 1.75$ & 5.44 & $0.001 * *$ \\
Platelets & $31.84 \pm 3.75$ & $37.33 \pm 3.25$ & 2.59 & $0.012^{*}$ \\
TNF -alpha before treatment & $272.35 \pm 89.39$ & $330.85 \pm 60.87$ & 8.59 & $0.001 * *$ \\
IL-6 before treatment & $13.03 \pm 4.79$ & $3.69 \pm 0.93$ & 10.4 & $0.001 * *$ \\
TNF- alpha after 7 days of treatment & $0.68 \pm 0.27$ & $0.06 \pm 0.01$ & 6.50 & $0.001 * *$ \\
IL-6 after 7 days of treatment & $8.02 \pm 2.88$ & $3.69 \pm 0.93$ & 6.97 & $0.001^{* *}$ \\
\hline
\end{tabular}


TABLE 2. Plasma levels of tumor necrosis factor alpha (TNF-alpha) and interleukin-6 (IL-6) in studied groups (group I was a response, group II was a resistance).

\begin{tabular}{|c|c|c|c|c|c|}
\hline Variable & $\begin{array}{c}\text { Group I } \\
(14) \\
\text { Mean } \pm \text { SD }\end{array}$ & $\begin{array}{l}\text { Group II (20) } \\
\text { Mean } \pm \text { SD }\end{array}$ & Variable & F test & P value \\
\hline \multicolumn{6}{|c|}{ TNF-alpha (pg/ml) } \\
\hline $\begin{array}{l}\text { TNF- alpha before } \\
\text { treatment }\end{array}$ & $7.96 \pm 1.03$ & $16.58 \pm 2.64^{\mathrm{a}}$ & $3.69 \pm 0.93^{\mathrm{ab}}$ & 269.2 & $0.001 * *$ \\
\hline $\begin{array}{l}\text { TNF- alpha after } 7 \\
\text { days of treatment }\end{array}$ & $5.13 \pm 0.80$ & $10.05 \pm 1.87 \mathrm{a}$ & $3.69 \pm 0.93 \mathrm{ab}$ & 121.77 & $0.001 * *$ \\
\hline \multicolumn{6}{|c|}{ IL-6 (pg/ml) } \\
\hline IL-6 before treatment & $0.45 \pm 0.13$ & $0.84 \pm 0.21^{\mathrm{a}}$ & $0.06 \pm 0.01^{\mathrm{ab}}$ & 142.49 & $0.001 * *$ \\
\hline $\begin{array}{l}\text { IL- } 6 \text { after } 7 \text { days of } \\
\text { treatment }\end{array}$ & $0.14 \pm 0.08$ & $0.38 \pm 0.09^{\mathrm{a}}$ & $0.06 \pm 0.01^{\mathrm{ab}}$ & 128.5 & $0.001 * *$ \\
\hline
\end{tabular}

$\mathrm{a}=$ significant with gp I, $\mathrm{b}=$ significant with gp II

TABLE 3. Laboratory characteristics in responsive and resistant patients. Comparison between group I (response) and group II (resistance).

\begin{tabular}{|c|c|c|c|c|}
\hline Variable & $\begin{array}{c}\text { Group I } \\
(14) \\
\text { Mean } \pm \text { SD }\end{array}$ & $\begin{array}{l}\text { Group II (20) } \\
\text { Mean } \pm \text { SD }\end{array}$ & t test & P value \\
\hline Sex No. (\%) Male Female & $\begin{array}{l}7(50.0 \%) \\
7(50.0 \%)\end{array}$ & $\begin{array}{l}12(60.0 \%) \\
8(40.0 \%)\end{array}$ & $\mathrm{X}^{2}=0.33$ & 0.56 \\
\hline Age & $20.39 \pm 12.34$ & $17.6 \pm 8.29$ & 0.79 & 0.44 \\
\hline RBCs & $3.56 \pm 1.06$ & $3.92 \pm 1.06$ & 0.98 & 0.34 \\
\hline $\mathrm{Hb}$ & $10.72 \pm 2.08$ & $11.39 \pm 2.47$ & 0.84 & 0.41 \\
\hline $\mathrm{MCV}$ & $79.38 \pm 6.71$ & $79.55 \pm 8.13$ & 0.07 & 0.95 \\
\hline $\mathrm{MCH}$ & $25.96 \pm 4.14$ & $28.5 \pm 3.90$ & 1.82 & 0.08 \\
\hline $\mathrm{MCHC}$ & $31.04 \pm 2.83$ & $32.71 \pm 2.87$ & 1.68 & 0.10 \\
\hline $\mathrm{HCT}$ & $30.5 \pm 3.55$ & $32.77 \pm 3.69$ & 1.79 & 0.08 \\
\hline Platelets & $260.57 \pm 97.68$ & $280.6 \pm 84.71$ & 0.64 & 0.53 \\
\hline $\operatorname{TLG}\left(\mathrm{x} 10^{3}-\mathrm{mm}^{3}\right)$ & $5.2 \pm 1.4$ & $6.6 \pm 2.6$ & & 0.23 \\
\hline $\operatorname{ESR}(\mathrm{mm} / \mathrm{h})$ & $60 \pm 8.7$ & $132.5 \pm 15.1$ & & $0.02^{*}$ \\
\hline $\mathrm{CRP}(\mathrm{mg} / \mathrm{L})$ & $27.5 \pm 9.1$ & $55 \pm 6.8$ & & $<0.001^{* *}$ \\
\hline TNF- alpha before treatment & $7.96 \pm 1.03$ & $16.58 \pm 2.64$ & 11.6 & $0.001^{* *}$ \\
\hline IL- 6 before treatment & $0.45 \pm 0.13$ & $0.84 \pm 0.21$ & 6.05 & $0.001^{* *}$ \\
\hline $\begin{array}{l}\text { TNF-alpha after } 7 \text { days of } \\
\text { treatment }\end{array}$ & $5.13 \pm 0.80$ & $10.05 \pm 1.87$ & 9.23 & $0.001^{* *}$ \\
\hline IL- 6 after 7 days of treatment & $0.14 \pm 0.08$ & $0.38 \pm 0.09$ & 8.31 & $0.001^{* *}$ \\
\hline
\end{tabular}


TABLE 4. Correlations between the measured cytokines ( TNF-alpha and IL-6) and some laboratory inquiry(Widal test before and after 7 days of treatment- and ESR) among cases groups.

\begin{tabular}{llccccc}
\hline \multirow{2}{*}{ Case group (34) } & & \multicolumn{2}{c}{ Before treatment } & After 7days of treatment & \multirow{2}{*}{ ESR } \\
\cline { 3 - 7 } & & r test & P value & r test & P value & r test \\
\hline \multirow{2}{*}{ TNF- alpha } & O test & 0.18 & 0.30 & 0.59 & $0.001^{* *}$ & $0.643^{*}$ \\
\multirow{2}{*}{ IL-6 } & H test & 0.07 & 0.70 & 0.55 & $0.001^{* *}$ & \\
& O test & -0.05 & 0.80 & 0.51 & $0.002^{* *}$ & $0.579^{*}$ \\
\hline
\end{tabular}

TABLE 5. Plasma levels of tumor necrosis factor alpha (TNF-alpha) and interleukin-6 (IL-6) in group I was a response. (Follow up before and after 7 days of treatment among group I).

\begin{tabular}{|c|c|c|c|c|}
\hline Group I & Before & After & Test & P value \\
\hline O test No. $(\%)$ & & & \multirow{6}{*}{ Mc Nemar } & \multirow{6}{*}{0.08} \\
\hline negative & $1(7.1 \%)$ & $7(50.0 \%)$ & & \\
\hline $1 / 80$ & $4(28.6 \%)$ & $4(28.6 \%)$ & & \\
\hline $1 / 160$ & $7(50.0 \%)$ & $2(14.3 \%)$ & & \\
\hline $1 / 320$ & $1(7.1 \%)$ & $1(7.1 \%)$ & & \\
\hline $1 / 640$ & $1(7.1 \%)$ & $0(0.0 \%)$ & & \\
\hline \multicolumn{5}{|l|}{ O test } \\
\hline Positive & $13(92.9 \%)$ & $7(50.0 \%)$ & \multirow[t]{2}{*}{ Mc Nemar } & \multirow[t]{2}{*}{$0.037^{*}$} \\
\hline Negative & $1(7.1 \%)$ & $7(50.0 \%)$ & & \\
\hline \multicolumn{5}{|l|}{$\mathrm{H}$ test $\mathrm{N}(\%)$} \\
\hline negative & $1(7.1 \%)$ & $6(42.9 \%)$ & \multirow{5}{*}{ Mc Nemar } & \multirow{5}{*}{0.08} \\
\hline $1 / 80$ & $4(28.6 \%)$ & $5(35.7 \%)$ & & \\
\hline $1 / 160$ & $5(35.7 \%)$ & $1(7.1 \%)$ & & \\
\hline $1 / 320$ & $2(14.3 \%)$ & $2(14.3 \%)$ & & \\
\hline $1 / 640$ & $2(14.3 \%)$ & $0(0.0 \%)$ & & \\
\hline \multicolumn{5}{|l|}{$\mathrm{H}$ test } \\
\hline Positive & $13(92.9 \%)$ & $8(57.1)$ & Mc Nemar & 0.08 \\
\hline Negative & $1(7.1 \%)$ & $6(42.9)$ & & \\
\hline TNF- alpha Mean \pm SD & $7.96 \pm 1.03$ & $5.13 \pm 0.80$ & Paired $t=27.6$ & $0.001 * *$ \\
\hline IL-6 Mean \pm SD & $0.45 \pm 0.13$ & $0.14 \pm 0.08$ & Paired $t=10.4$ & $0.001 * *$ \\
\hline
\end{tabular}

TABLE 6. Plasma levels of tumor necrosis factor alpha (TNF- alpha) and interleukin-6 (IL-6) in group II was a resistant (Follow up before and after7 days of treatment among group II).

\begin{tabular}{|c|c|c|c|c|}
\hline Group II & $\begin{array}{c}\text { Before } \\
\text { treatment }\end{array}$ & $\begin{array}{c}\text { After } 7 \text { days of } \\
\text { treatment }\end{array}$ & Test & P value \\
\hline $\begin{array}{l}\text { O test No.(\%) } \\
1 / 80 \\
1 / 160 \\
1 / 320 \\
1 / 640\end{array}$ & $\begin{array}{c}1(5.0 \%) \\
12(60.0 \%) \\
6(30.0 \%) \\
1(5.0 \%)\end{array}$ & $\begin{array}{c}1(5.0 \%) \\
10(50 . \% 0) \\
8(40.0 \%) \\
1(5.0 \%)\end{array}$ & Mc Nemar & 0.93 \\
\hline $\begin{array}{l}\text { H test } \quad \mathrm{N}(\%) \\
1 / 80 \\
1 / 160 \\
1 / 320 \\
1 / 640\end{array}$ & $\begin{array}{c}3(15.0 \%) \\
10(50.0 \%) \\
6(30.0 \%) \\
1(5.0 \%)\end{array}$ & $\begin{array}{c}3(15.0 \%) \\
8(40.0 \%) \\
8(40.0 \%) \\
1(5.0 \%)\end{array}$ & Mc Nemar & 0.92 \\
\hline TNF- alpha Mean \pm SD & $16.58 \pm 2.64$ & $10.05 \pm 1.87$ & Paired $\mathrm{t}=28.63$ & $0.001 * *$ \\
\hline IL-6 Mean \pm SD & $0.84 \pm 0.21$ & $0.38 \pm 0.09$ & Paired $\mathrm{t}=13.49$ & $0.001 * *$ \\
\hline
\end{tabular}


Also, TNF- alpha and IL-6 plasma levels were highly significant before treatment than after 7 days of treatment in resistance (group II).

\section{Data management}

The clinical data are record in a report format. The datum are tabulate and analyze by the computer program SPSS (Statistical package for social science) version 20 to get:

\section{Descriptive data}

Descriptive statistics are calculate for this datum in the format of:

1. Mean and standard deviation (+SD) for quantitative datum

2. Frequency and distribution for qualitative datum.

\section{Analytical statistics}

In the statistical comparison among the several sets, the significant of differences is tested by one of the followings tests:

1. Student's t-test: Used to compared means of 2 sets of quantitative datum.

2. Paired t test: Used to compared means of changes in various timing period of quantitative datum.

3. ANOVA test (F value): Used to compared means of more than 2 sets of quantitative datum.

4. Inter-group differentiation of serial datum is completed by use chi square test ( $X^{2}$-value).

5. Correlation coefficient ( $r$ test): To get relationships among variables.

Pvalue $<0.05$ is consider statistically significant (*) while $>0.05$ statistically insignificant whever $\mathrm{P}$ value $<0.01$ is consider significant high (**) in all analysis

\section{Discussion}

According to the clinical response to a combination of cefotax and ciprofloxacin in addition to zithrokan and zantac we categorized the patients into two sets in this study. Responders were 14 cases $(41.2 \%)$ and 20 resistant patients $(58.8 \%)$. This average rate of responses is like to that reported by another searches. (Abou El-Hasan et al.,1998 and Tohme et al., 2004).

In this search, high fever, toxic look, designated splenomegaly, constipation and elevate CRP are significant identify resistant patients. The difference in age, as children and infants can explain the difference in the frequency of clinical, for example, evolve diarrhea instead of constipation (Ashkenazi $\&$ Cleary, 2008). And might be due to difference in endotoxin production, regional inflammatory and/or host immune reactions among resistant and responsive patients (Pramoolsinsap \& Viranuvatti, 1998). Through this search, resistant patients have a highly significant ESR than cases whose respond to drug therapy (Wyant et al., 1999). This increase is refer to increase of IL-6, also deemed it among the main physiological mediators of severe stage effect. They proven these statement with significant positive correlations of IL-6 with fever. In our cases the CRP and ESR have maximum significant IL-6 levels, before therapy comparison between control cases. Increasing of IL-6 levels might be due to increased IL-6 gene expression in human monocytes, which catalyze antigen by Salmonella typhi proteins (Kogut, 2005). Additionally bacterial is commonly knowledge by intestinal epithelial cells via toll-like receptors to trigger the cellular immune reactions, where raised IL-6 is one of its expressing (Iankov et al., 2004). Resistant patients have highly significant IL-6 levels before therapy, compared to responsive patients, explaining expectations of value of IL-6. It is agrees with Bhutta et al. (1997). The slope of IL-6 Is significant in both all cases (resistant and responsive) after 7 days of treatment. The inflammatory role of IL- 6 and that it is one of the mediators in charge of continuation of inflammatory demonstration, particularly in resistant cases (Li et al., 2003). In this search, TNFalpha was higher significantly in all cases than control cases and more clear in resistant patients compared to responsive patients all before and after 7 days of treatment. This in agreement with Beutler (1999) who reported high levels of TNFalpha, in resistant cases, correlating with elongate fever or relapse after treatment with cefotax and ciprofloxacin, when parallel with responsive cases. They complemented that high levels of TNF-alpha maigh be qualified of bond TNF and so boosting its harmful effects. It observed that after 7 days of treatment the TNF-alpha levels reject significantly and it is agreement with Wyant et al. (1999), who reported that prompting with Salmonella typhi flagella has stimulate rapid de novo synthesis of TNF-alpha, through acute typhoid disease which reduce with recovery. After correlation of studied cytokines and some laboratory datum. After treatment there was significant positive correlation of IL-6 with Salmonella typhi O and $\mathrm{H}$ agglutination titre and with ESR $(\mathrm{r}=0.578)$. This result was agrees with Zherebtsova et al. (2007), who found medium positive reaction among the 
scale of IL-6 and variation in plasma of blood included ESR. As well our research presents significant positive correlations of TNF-alpha with S. typhi $\mathrm{O}$ and $\mathrm{H}$ agglutination titer after treatment also with ESR which can reverse the positive activities of those cytokines (Enedetti et al., 1997). In conclusion, the studied patients with typhoid fever whose are resistant to therapy with cefotax and ciprofloxacin additionally zithrokan and zantac have higher levels of IL-6 and TNF-alpha than these whose had been responded cases. Toxic look, constipation and splenomegaly might be looked at as signals of drug resistance. In the pathogenesis of typhoid fever the IL-6 and TNF-alpha have a role, so we recommend other searches to determine the accurate role of immunomodulation in curing resistant patients. Selection of interleukin -6 and tumor necrosis factor -alpha as 'key' cytokines that some research has proven a relationship between these cytokines (IL-6 and TNF- alpha) and typhoid fever, levels of the cytokines TNFalpha and IL-6 are elevated in the blood of patients with typhoid fever (Roine et al., 1990). Because disease severity in meningococcemia (Waage et al., 1989) and gram- negative sepsis (Wortel et al., 1992). Correlates with concentrations of IL-6 in blood, measurement of cytokines may offer a new dimension in the estimate of the clinical effectiveness of antimicrobial therapy. The cytokines, including TNF and IL-6 are important mediators of signs and symptoms of infectious disease (Elias, 1992 and Kern et al., 1992).

Measuring the levels of cytokines (IL-6 and TNF) in human plasma before therapy clarify that is possible to have resistance to treatment and when the treatment was done, already found some patients resistance to antibacterial therapy and by measuring the level of cytokines in these resistance patients we found high levels of these cytokines in their plasma. So I recommend completing this search by giving patients a combination of antibacterial and anti inflammation therapy to inhibit the levels of cytokines and so we increase the immunity of these patients thus making them easy to respond to therapy.

\section{Conclusion}

Measurement of cytokines may offer a new dimension in the estimate of the clinical effectiveness of antimicrobial therapy. The cytokines, including TNF and IL-6 are important mediators of signs and symptoms of infectious disease. Measuring the levels of cytokines (IL6and TNF) in human plasma before therapy clarify that is possible to have resistance to treatment and when the treatment was done, already found some patients resistance to antibacterial therapy and by measuring the level of cytokines in these resistance patients we found high levels of these cytokines in their plasma. So I recommend completing this search by giving patients a combination of antibacterial and anti inflammation therapy to inhibit the levels of cytokines and so we increase the immunity of these patients thus making them easy to respond to therapy.

\section{$\underline{\text { References }}$}

Abou El-Hasan, S.M., Abou El-Khair, M.M., Shaltout, A.A., El-Shennaway, F.A. and Soliman, O.E. (1998) Study of some cytokines and adhesion molecules in children with typhoid and paratyphoid fever. Egypt. J. Med. Microbiol. 7(2), 445-52.

Ashkenazi, S. and Cleary, T. (2008) Salmonella infections. In: "Nelson Textbook of Pediatrics", Behrman, E.R., Kleigman, M.R., Arvin, M.A. (Ed), pp. $812-7,18^{\text {th }}$ ed. Philadelphia, W.B. Saunders Co.

Baker, S., Karkey, A. and Parry, C, (2014) Are we adequately prepared for the emergence of Salmonella enterica serovar Paratyphi A? Lancet Glob Health, 2(4), e195-e196

Beutler, B.A. (1999) The role of tumor necrosis factor in health and disease. J. Rheumatol. Suppl. 57, 16-21.

Bhutta, Z.A, Mansoorali, N. and Hussain, R. (1997) Plasma cytokines in pediatric typhoidal salmonellosis: Correlation with clinical course and outcome. $J$. Infect. 35(3), 253-263.

Choo, K.E, Davis, T.M., Henry, R.L. and Chan, L.P. (2001) CRP concentration in Malysian children with enteric fever. J. Trop. Pediatr. 47(4), 211-4.

Ciacci-Woolwine, F., Blomfied, I.C., Richardson, S.H. and Mizel, S.B. (1998) Salmonella flagellin induces tumour necrosis factor alpha in a human promonocytic cell line. Infect. Immun. 66, 1127-1134. '

Crump, J.A., Youssef, F.G., Luby, S.P., Wasfy, M.O., Rangel, J.M. and Toalat, M. et al. (2003) Estimating the incidence of typhoid fever and other febrile illnesses in developing countries. Emerg. Infect. Dis. 9(5), 539-44. 
Dougan, G. and Baker, S. (2014) Salmonella enterica serovar Typhi and the pathogenesis of typhoid fever. Annu. Rev. Microbiol. 68, 317-336.

Elias, J.A. (1992) Interleukin-6: On target for disease and approaching the bedside. J. Lab. Clin. Med. 120, 672674.

Enedetti, F.D.E., Pignatti, P., Massa, M., Sartirana, P., Ravelli, A. and Cassani, G. et al. (1997) Soluble tumour necrosis factor receptor levels reflect coagulation abnormalities in systemic juvenile chronic arthritis. Br. J. Rheumatol. 36, 581-88.

Engelmann, H., Holtmann, H., Brakebush, C., Avni, Y.S., Sarov, I. and Nophar, Y. et al. (1990) Antibodies to a soluble form of tumor necrosis factor (TNF) receptor have TNF like activity. J. Biol. Chem. 265(14), 497504.

Fabrega, A. and Viola, J. (2013) Salmonella enterica serovar Typhimurium skills to succeed in the host: Virulence and reulation. Clinical Microbiology Reviews, 26(2), 308-341. doi:10.1128/CMR. 00066 -12.ISSN 0893-8512.

Fangtham, M. and Wilde, H. (2005) Emergence of Salmonella paratyphi A as a major cause of enteric fever: Need for early detection, preventive measures and effective vaccines. J. Travel. Med. 15(15), 344-350.

Felix, A. (1944) Trans. Roy. Soc. Trop. Med. Hyg. 37, 321.

Greisman, S.E., Hornick, R.B., Wagner, H.N. jr., Woodward, W.E. and Woodward, T.E. (1969) The role of endotoxin during typhoid fever and tularemia in man.I. The integrity of the endotoxin tolerance mechanisms during infection. J. Clin. Invest. 48, 613-29.

Henderson, B., Poole, S. and Wilson, M. (1996) Bacterial modulins: A novel class of virulence factors which cause host tissue pathology by inducing cytokine synthesis. Microbiol. Rev. 60, 316-341.

Iankov, I., Atanasova, G., Maria Praskova, Silvia Kalenderova, Petrov, D. and Mitev, V. et al. (2004) Bacterial lipopolysacharide induces proliferation of IL-6 dependent plasma cytom cells by MARK pathway activation. Immunobiology, 208(5), 445-54.
Joint (1995) FAO/WHO Expert Committee on Brucellosis. Wld. Hlth. Org. Tech. Rep. Ser. 148:1

Kern, P., Hemmer, C.J., Gallati, H., Neifer, S., Kremsner, P., Dietrich, M. and Porzsolt, F. (1992) Soluble tumor necrosis factor receptors correlate with parasitemia and disease severity in human malaria. J. Infect. Dis. 166, 930-934.

Keuter, M, Dharmana, E, Gasem, M.H, Van derjongekrijg, J., Djokomoeljanto, R. and Dolmans, W.M. et al. (1994) Patterns of proinflammatory cytokines and inhibitors during typhoid fever .J Infec. Dis. 169, 1306-11.

Kogut (2005) Centers for disease control and prevention. National Centers for Infectious Diseases, Division for Bacterial and Mycotic Diseases.

Kogut, M.H., Rothwell, L. and Kaiser, P. (2005) Interferon gamma priming of chicken heterophils upregulates the expression of proinflammatory and $\mathrm{T}$ helper-I cytokine mRNA following receptormediated phagocytosis of Salmonella enterica serovar enteritidis. J. Interferon Cytokine Res. 25(2), 73-81.

Levine, M.M., Ferreccio, C., Cryz, S. and Ortiz, E.(1990) Comparison of enteric coated capsules and liquid formulation of Ty 2la typhoid vaccine in randomized controlled field trial. Lancet, 336, 891-4.

Li, Y., Reichenstein, K., Ullrich, R., Danner, T., von Specht, B.U. and Hahn, H.P. (2003) Effect of in situ expression of human interleukin- 6 on antibody responses against Salmonella typhi urium antigens. FEMS Immunol. Med. Microbiol. 37, 135-45.

Liles, W.C. and Van Voorhis, W.C. (1995) Review: nomenclature and biologic significance of cytokines involved in inflammation and the host immune response. J. Infect. Dis. 172, 1573-1580.

Mastroeni, P. and Menager, N. (2003) Development of acquired immunity to Salmonella. J. Med. Microbiol. 52, 453-9.

Miller, S.I., Hohmann, E.I. and Pegus, D.A. (1995) Salmonella. In: "Principles and Practice of Infectious Diseases", Mandell, G.L., Bennett, J.E., Dolin, R. (Ed.), pp. 2013-33, $4^{\text {th }}$ ed. New York, Churchill Livingstone.

Old, D.C. (1996) Salmonella. In: "Practical Medical 
Microbiology", Mackie and McCartney, pp. 385$402,14^{\text {th }}$ ed. London, Churchill Livingstone.

Pramoolsinsap, C. and Viranuvatti, V. (1998) Salmonella hepatitis. J. Gastroenterol. Hepatol. 13(7), 745-50.

Roine, I., Herrera, P., Ledermann, W. and Peltola, H. (1990) Program Abstr. 30 In Intersci. Conf. Antimicrob. Agents Che mother, abstr. p.299

SU, L.H. and Chiu, C.H. (2007) Salmonella: Clinical importance and evolution of nomenclature. Change Gung Medical Jornal, 30(3), 210-9. PMID 17760271.

Tohme, A., Zein, E. and Nasnas, R. (2004) Typhoid fever, Clinical and therapeutic study in 70 patients. J. Med. Liban. 52(2), 71-7.

Tortora, G.A. (2008) "Microbiology: An Introductional", Pearson (Ed.), pp. 323-324, $9^{\text {th }}$ ed. ISBN 81317722325.

Waage, A., Brandtzag, P., Halstensen, A., Kierutf, P. and Espevik, T. (1989) The complex pattern of cytokines in serum from patients with meningococcal septic shock. Association between interleukin 6, interleukin 1, and fatal outcome. Exp. Med. 169, 333-338.
Wain, J., Hendriksen, R.S., Mikoleit, M.L., Keddy, K.H. and Ochiai, R.L. (2015) Typhoid fever. Lancet, 385(9973), 1136-1145.

Wilson, M., Seymour, R. and Henderson, B. (1998) Bacterial perturbation of cytokine networks. Infect. Immun. 66, 2401-2409.

Wortel, C.H., von der Moblen, M.A.M., van Deventer, S.J.H., Sprung, C.L., Jastremski, M., Lubbers, M.J., Smith, C.R., Allen, L.E. and ten Cate, J.W. (1992) Effectiveness of a human monoclonal antiendotoxin antibody (HA 1A) gram negative sepsis; relationship to endołoxin and cytokine levels. $J$. Infect. Dis. 166, 1367-1374.

Wyant, T.L, Tanner, M.K. and Sztein, M.B. (1999) Salmonella typhi flagella are potent inducers of proinflammatory cytokine secretion by human monocytes. Infect. Immun. 67(7), 3619-24.

Zaidi, A.K., Hasan, R. and Bhutta, Z.A. (2003) Typhoid fever. N. Eng. J. Med. 348(12), 1182-4.

Zherebtsova, N., Valishin, D.A. and Mavziutov, A.R. (2007) Proinflammatory cytokines in children with acute enteric infections caused by enterobacteria. Zh. Mikrobid. Epidemiol. Immunobiol. 3, 48-52.

(Received 29/5/2018; accepted $2 / 9 / 2018$

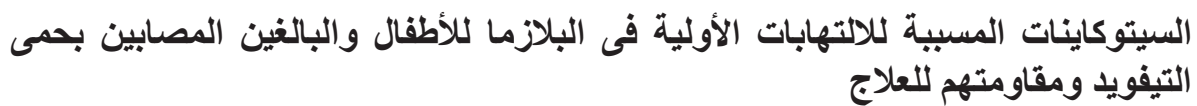

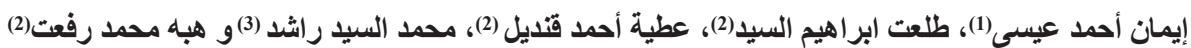

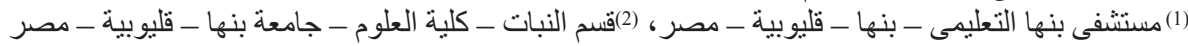
و (3)الهيئة الدولية للمقاومة البيولوجية والبحوث - القاهرة - مصر.

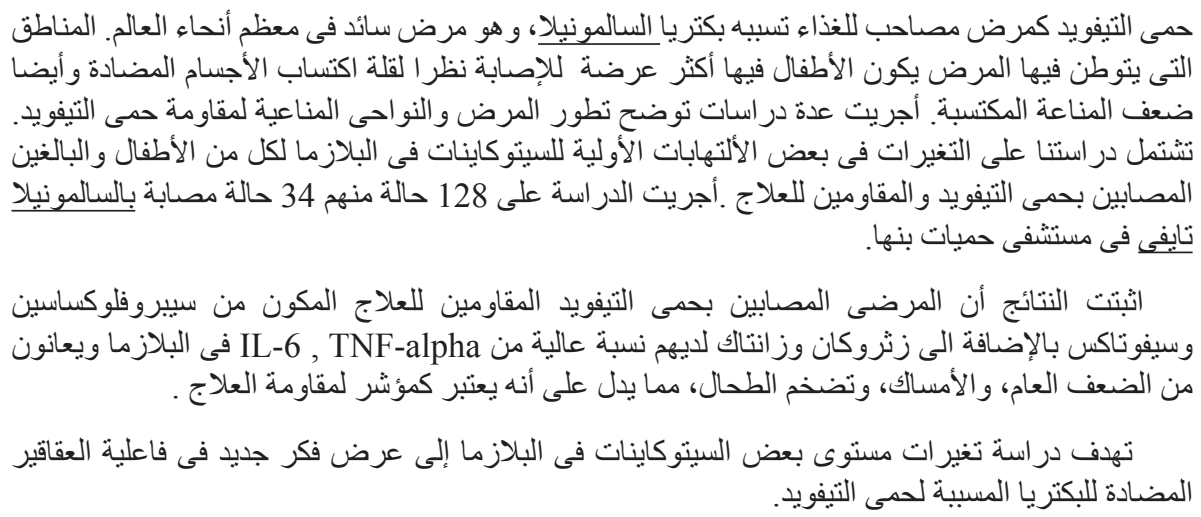

